H A R VAR D

\title{
Extending Producer Responsibility: An Evaluation Framework for Product Take- Back Policies
}

Michael W. Toffel

Antoinette Stein

Katharine L. Lee

\section{Working Paper}

09-026 


\title{
Extending Producer Responsibility: An Evaluation Framework for Product Take-Back Policies
}

\author{
Michael W. Toffel ${ }^{1}$ \\ Harvard Business School, Soldiers Field Road, Boston MA 02163 \\ Antoinette Stein ${ }^{2}$ \\ Environmentally Preferable Purchasing Program, \\ State of California Department of General Services Procurement Division, \\ 707 Third Street, West Sacramento, CA 95605 \\ Katharine L. Lee \\ Harvard Business School, Soldiers Field Road, Boston MA 02163
}

September 1, 2008

\begin{abstract}
Manufacturers are increasingly being required to adhere to product take-back regulations that require them to manage their products at the end of life. Such regulations seek to internalize products' entire life cycle costs into market prices, with the ultimate objective of reducing their environmental burden. This article provides a framework to evaluate the potential for take-back regulations to actually lead to reduced environmental impacts and to stimulate product design changes. It describes trade-offs associated with several major policy decisions, including whether to hold firms physically or financially responsible for the recovery of their products, when to impose recycling fees, whether to include disposal and hazardous substance bans, and whether to mandate product design features to foster reuse and recycling of components and materials. The framework also addresses policy elements that can significantly affect the cost efficiency and occupational safety hazards of end-of-life product recovery operations. The evaluation framework is illustrated with examples drawn from take-back regulations promulgated in Europe, Japan, and the United States governing waste electrical and electronic equipment (WEEE).
\end{abstract}

Managing products at the end of life (EOL) is of growing concern for durable goods manufacturers. Whereas some manufacturers engage in voluntary take back of EOL products for a variety of competitive reasons (Toffel, 2004), the past decade has seen the rapid proliferation of government regulations and policies requiring manufacturers to collect and recycle their products, or pay others to do so on their behalf. These product "take back" regulations and policies represent an innovative approach to reducing the volume and toxicity of waste. Applying

\footnotetext{
${ }^{1}$ Corresponding author phone: (617) 384-8043; e-mail: mtoffel@hbs.edu

${ }^{2}$ Affiliated with University of California-Davis/Irvine while conducting this research.
} 
the "polluter pays principle" that calls on governments to "take those actions necessary to ensure that polluters and users of natural resources bear the full environmental and social costs of their activities” (Hunter, Salzman, and Zaelke, 2002), these policies impose part or all of the recycling and disposal costs on manufacturers.

A few scholars have begun the important work of evaluating the environmental impacts of particular take back policies in Japan (Ogushu and Kandlikar, 2007) and Europe (BarbaGutierrez, Adenso-Diaz, and Hopp, 2008; Gerrard and Kandlikar, 2007; Hischier, Wager, and Gauglhofer, 2005), albeit constrained by limited data given the novelty of these policies. ${ }^{3}$ Further complicating such analysis are varying approaches to measuring environmental performance (Huppes and Ishikawa, 2005; Michelsen, Magerholm Fet, and Dahlsrud, 2007; Toffel and Marshall, 2004). However, the literature lacks an analysis of how key elements of take-back policies can affect their ability to achieving their objectives of reducing environmental impacts, including by stimulating produce redesign that considers recyclability. In this article, we describe such a framework, and include an analysis of how certain policy features can affect the cost efficiency of, and occupational safety associated with, EOL product recovery. In doing so, we seek to provide guidance to policy makers, managers, and scholars who are contemplating formulating, responding to, and assessing take-back policies.

In summary, our evaluation identifies key take back policy elements that may be used to reduce harm to the environment and public health and the occupational health and safety of those involved in recovery operations, and to encourage cost efficiency (see Figure 1). The framework describes tradeoffs involved in mandating financial or physical responsibilities; imposing advanced- or end-of-life recycling fees; allowing collective (versus individual)

\footnotetext{
${ }^{3}$ In addition, prior research has explored manufacturers' strategic responses to product take-back regulations (Crotty and Smith, 2006; Toffel, 2003).
} 
recycling operations; requiring recycler and waste processor certifications; and including recovery and recycling targets, disposal bans, substance bans, design-for-environment requirements, and export controls. The evaluation framework is illustrated with examples drawn from take-back regulations promulgated in Europe, Japan, and the United States. This framework focuses on the product category of waste electrical and electronic equipment (WEEE) because it is the target of many, and perhaps most, government take back policies around the world. Nonetheless, our framework is readily applicable to take-back policies that govern other categories of durable goods as well.

\section{Figure 1. Take-back policy features}

\section{Mitigating environmental and public health risks}

- Recovery and recycling targets

- Timing of recycling fees

- Disposal bans

- Substance bans

- Design and substance requirements

\section{Promoting cost efficiency}

- Financial versus physical responsibility

- Individual versus collective operations

- Appropriate advanced disposal fees

\section{Protecting occupational health and safety}

- Recycler and waste processor certification

- Export controls

\section{Policy rationale}

Imposing part or all of the costs of recovering and recycling EOL products on their producers is meant to create incentives for producers to modify product designs in ways that minimize such costs, such as by facilitating the reuse and recycling of components and materials 
(Hanisch, 2000; Toffel, 2003). It also represents a movement to privatize the costs of this growing source of waste, both to unburden governments and to tap the private sector's profit motive in anticipation that improved operational efficiency will reduce EOL product management costs. For example, when take-back laws in Japan shifted these responsibilities from the Tokyo Metropolitan Government to the private sector, the latter reduced recycling costs of major home appliances by more than half (Ogushu and Kandlikar, 2007).

Take-back regulations also seek to reduce environmental impact under the assumption that this occurs when greater proportions of end-of-life products, components, and materials are reused, recycled, and recovered (Mayers, France, and Cowell, 2005). This assumption is based on a life cycle-based principle that posits that, compared to landfill disposal, the environmental burden of end-of-life product management is reduced the greatest by measures to prevent disposal such as durability, followed by reuse, followed by recycling. Indeed life cycle studies of end-of-life disposal of waste electrical and electronic equipment (WEEE) have provided some empirical support for this conventional "Reduce, Reuse, Recycle” waste management hierarchy (Brinkley et al., 1994; McLaren et al., 1999).

To ensure that the intended shift from disposal to recycling occurs in practice once EOL management responsibilities shift from the government to the private sector, many take-back regulations impose minimum collection and recycling thresholds. These targets seek to reduce the amount of hazardous materials disposed of in landfills and incinerators, increase the availability of recyclable and recycled materials to encourage their substitution for virgin materials, and thereby reduce the life cycle environmental burden of both current and next generation products (Toffel, 2003). 


\section{Policy proliferation}

Take-back regulations have targeted a wide array of products including packaging, batteries, automobiles, and electronics (Toffel, 2003). WEEE is the most frequent target of takeback regulations because it is both a fast growing portion of the waste stream and often contains hazardous materials and potentially recyclable materials such as metals (European Commission, 2002). Take-back regulations have been enacted over the past decade in many European and East Asian nations (Toffel, 2003). In the United States, the states of Connecticut, Maine, Minnesota, North Carolina Oregon, Texas, and Washington have passed take-back regulations that require producers to pay at least some portion of end-of-life collection and recycling costs of WEEE. Several attempts to pass federal legislation in the United States have failed (Electronics Take Back Coalition, 2008). Perhaps the most comprehensive example is the European Union's (EU) Directive on Waste Electrical and Electronic Equipment (WEEE Directive), which took effect in August 2005 (European Parliament and European Council, 2003c). The WEEE Directive "seeks to minimize the impact of electronic equipment on the environment both during its product lifetime and when it becomes waste by making the manufacturer responsible for both disposal and recycling” (Quinell, 2005). The directive requires EU member states to pass legislation that imposes all recycling and waste management costs of WEEE on the producers of the products, including transportation costs from collection centers.

\section{Mitigating environmental and public health risks}

The primary goal of product take-back regulations governing electronic products is to reduce the environmental impacts and public health risks associated with their production, use, and disposal. In part, these concerns result from obsolete electronic products constituting one the fastest growing waste streams, much of which contains hazardous substances that can leach into 
groundwater if disposed of in conventional landfills (California Department of Toxic Substance Control, 2001; Musson et al., 2000; Yang, 1993) or pollute the air when incinerated. They are often difficult to recycle due to these and other toxins such as flame retardants, and due to the fact that many have not been designed for deconstruction. For example, the picture tubes in CRT monitors and televisions, which contain several pounds of lead embedded in the glass, have failed leachability tests, suggesting significant risk of contaminating groundwater. Incinerating these wastes is also problematic because the associated heating and cooling cycles have the potential to induce the formation of hazardous by-products that can be emitted into the air as well as of high concentrations of toxic substances in the remaining slag, fly ash, char, and filter cake (Silicon Valley Toxics Coalition, 1999; US Environmental Protection Agency, 1989).

In this section, we describe take-back policy features that seek to reduce harm to the environment and public health. These might address product disposal, such as by imposing recycling targets and disposal fees or banning EOL products from municipal solid waste streams. They might target product design, such as by banning or requiring the use of particular materials or by mandating particular design features. Below, we describe these features and how they can reduce environmental harm, in many cases providing examples of regulations that embody these features.

\section{recovery and recycling targets}

Take-back regulations might stipulate that particular proportions of EOL products be recovered and recycled. Many of these targets, including those imposed by the European Union's WEEE Directive, are based on product mass. The EU directive requires producers of IT and telecommunications equipment to recover "a minimum of $75 \%$ by an average weight per appliance" and reuse and recycle "a minimum of $65 \%$ by an average weight per appliance." Scholars have raised serious concerns that mass-based targets are a poor proxy for achieving the 
policy objective of minimizing life cycle environmental impacts (Atlee and Kirchain, 2006; Huisman, 2004), and that such targets can create perverse incentives (Huisman et al., 2006; Mayers et al., 2005). For example, mass-based targets could create incentives for producers to employ heavy but easily recyclable materials instead of lighter disposable materials, even when the latter would result in lower life cycle environmental impacts (Ferrao, Nazareth, and Amaral, 2006; Huisman et al., 2006; Mayers et al., 2005). Instead of mass-based targets, these scholars and practitioners call for regulators to impose "specific environmental objectives and operating standards for treatment and recycling processes” (Mayers et al., 2005), and to choose targets based on "environmental weights" that account for relative environmental impacts throughout the life cycles of products and materials (Huisman et al., 2006). These more refined targets seem far more likely to help take-back regulations achieve their potential for reducing environmental impacts while avoiding perverse incentives, although it is unclear how complicated and customized such targets should be. For example, ideal targets from an environmental perspective might vary substantially by geography (e.g., urban/rural, distance to recyclers) and product classification (e.g., based on material composition), but implementing overly customized targets for these factors could conflict with other policy concerns including equity across political boundaries and simplicity for EOL product owners.

\section{Timing of recycling fees}

Take-back policies might stipulate particular disposal fees to cover the cost of recycling. Some policies require these fees to be imposed at the time of purchase ("advanced disposal [or recovery] fees”), others at the time of disposal. In Japan, the timing varies by product: fees are collected at the time of purchase for computers and automobiles, and upon disposal for home appliances (Ogushu and Kandlikar, 2007). California imposes a uniform advanced disposal fee on all covered electronic products. 
Requiring disposal fees to be paid at the time of purchase rather than upon disposal offers two benefits. First, these fees are effectively incorporated in the purchase price of products, which enable prices to better reflect products' life cycle costs. Second, advance disposal fees avoid the disincentives for proper disposal created by disposal fees charged at the time of disposal. Because the latter require payment of a disposal fee at the time of disposal some owners of regulated EOL products might attempt to illegally mix their EOL products into the municipal waste stream or illegally dump them. For example, illegal disposal of major household appliances increased substantially after Japan imposed disposal fees on these products (Ogushu and Kandlikar, 2007).

California's experience its advance disposal fee highlights one drawback of this approach: the need to accurately project costs. In 2007, the cumulative advance recovery fees the state had been collecting since its take back regulations took effect in 2004 were depleted, forcing the state to significantly raise the advanced recovery fee. California's unusual policy, in reality a form of a sales tax, allowed the state to reassess its fee every two years to ensure it paid for the collection and recycling costs of all covered waste electronics products. ${ }^{4}$ If manufacturers (or governments) set recovery fees at the time a particular electronics product were collected, they could more accurately forecast its collection and recycling costs given prevailing technologies and scale economies.

\section{Disposal bans}

Take-back regulations that stipulate recycling targets do not require 100 percent recycling rates, as achieving such a high rate is generally acknowledged to be prohibitively expensive. Thus, even under regimes with stringent take-back regulations, some fraction of WEEE is still

\footnotetext{
${ }^{4}$ California Integrated Waste Management Board, California Electronic Waste Recycling Act General Stakeholder Meeting, November 5, 2007.
} 
expected to be deposited in landfills or incinerated, and its hazardous materials component might thus still be cause for environmental concern. This risk can be further reduced by disposal bans. For example, a 2006 New Hampshire law banned the disposal of video display devices in conventional landfills and incinerators. Other states, including California, Maine, and Massachusetts, have imposed similar bans. By redirecting WEEE from landfills and incinerators to recycling outlets, disposal bans can also increase the supply of materials recovered from these products (e.g., glass from CRTs) (Toto, 2003). This lowers the cost of recycled materials, which can encourage their substitution for virgin materials.

When accompanied by disposal fees charged at the time of disposal, disposal bans carry a risk of leading owners to stockpile WEEE within their homes or offices. For example, the US EPA estimates that, in 2005, 180 million EOL computers and televisions remained in storage (US Environmental Protection Agency Office of Solid Waste, 2007). Delaying the entry of WEEE to recycling markets diminishes its ability to offset demand for the virgin materials for which it could substitute.

\section{Substance bans}

Policy makers can prevent particular substances from WEEE from harming the environment or posing a risk to public health by banning those substances from products. The EU took this unusual step when it implemented the Restriction of the Use of Certain Hazardous Substances in Electrical and Electronic Equipment (RoHS) Directive, which took effect in 2006 (European Parliament and European Council, 2003b). This directive banned mercury, cadmium, lead, chromium VI, and two brominated flame retardants from electronics sold in the EU due to concerns about the impact of these substances on human health and the environment. The EU took this fairly drastic step based on the view that these substances "would be likely to pose risks to health or the environment" even if the products that contained them were recycled (European 
Parliament and European Council, 2003a). Such policies can ban some toxic substances for which alternatives already exist, and also spur the development of new alternatives. For example, the EU's RoHS Directive was the "primary force" that drove the development of lead-free solder for use with electronics (Schoenung et al., 2004). China has implemented regulations quite similar to the EU’s RoHS Directive (People's Republic of China Ministry of Commerce, 2006), and Japan has implemented an ordinance that requires that special warning labels be affixed to products that contain any of the six substances banned by the EU's RoHS Directive (Japan's Ministry of Economy Trade and Industry, 2006).

\section{Design-for-environment requirements}

While product design can significantly affect the product's life cycle environmental impact and the efficiency of reverse logistics operations (Krikke, Bloemhof-Ruwaard, and Van Wassenhove, 2003; Walter and Spengler, 2005). a minority of products are designed with disassembly and recycling in mind (Pagell, Wu, and Murthy, 2007). This is perhaps unsurprising, given that conventional disposal regulations provide no incentives for manufacturers to invest in increasing the recyclability or reducing the recycling costs of their EOL products. Take-back regulations structured to impose on producers the costs of recycling and disposing of their own EOL products, by forcing the internalization of these costs, could provide sufficient incentive for producers to amend their product designs to facilitate recycling and avoid costly handling of hazardous substances. As explained below, policies often allow producers to engage in collective approaches that, while reducing costs by tapping economies of scale, leave producers with much weaker incentives to make such investments.

Policy makers have an even more direct option for stimulating design investments: they can mandate particular design features. Policies could, for example, require producers to make toxic components easily visible and removable, direct producers to label the material content of 
plastics and other difficult to identify materials, and encourage or require the use of materials that can be recycled multiple times and for which recycling markets exist. Such policy requirements are rare. The European Union came close when it established with its Directive on the eco-design of Energy-using Products (EuP), which took effect August, 2007, a framework for environmental design considerations for a variety of products (European Parliament and European Council, 2005). The directive calls on manufacturers to conduct an environmental assessment of their products that considers the full product life cycle, and to make design improvements that enhance their environmental performance. It does not, however, impose legal obligations on manufacturers. The initial focus of the directive was on electric motor systems, HVAC equipment, water heaters, domestic appliances, consumer electronics, office equipment, and lighting (EIATRACK, 2007). In the United States, President George W. Bush’s Executive Order 13423, issued in January 2007, requires all federal agencies to ensure that 95 percent of the electronic products they purchase meet the Electronic Product Environmental Assessment Tool (EPEAT) standard (Bush, 2007). The EPEAT standard imposes a variety of product design requirements including identifying materials that require special handling and the contents of plastic components, and avoiding certain substances including those restricted by the EU RoHS Directive .

Policies can also require producers to incorporate minimum thresholds of recycled content or recyclable content in their products, which could simultaneously increase the demand for recycled materials, reduce the flow of recovered materials to landfills or incineration, and reduce demand for virgin materials. For example, the EPEAT criteria requires at least 65 percent of products' materials be reusable or recyclable using current infrastructure and technologies (Bush, 2007). Outside the domain of WEEE, the EU's End of Life Vehicle Directive (2006) 
requires that all automobiles manufactured in the EU for domestic use have a recyclable content of 85 percent (95 percent by 2015) so that each vehicle that is manufactured can be reclaimed, dismantled, and recycled at the end of its useful life (Crotty, 2006). Replacing virgin materials with recycled materials yields environmental benefits when the latter require less energy, as is the case with glass cullet recovered from EOL CRTs (Enviros, 2002). The latter also avoids the environmental impacts associated with extraction of nonrenewable resources such as metals.

\section{Promoting cost efficiency}

Take-back policies can incorporate varying degrees of regulatory flexibility that can dramatically affect compliance costs. We focus on two forms of regulatory flexibility: the type of responsibility assigned to parties, and the extent of operational flexibility permitted.

\section{Cost efficiency from financial, rather than physical, responsibility}

Policies that impose on producers the physical responsibility for collecting, transporting, and recycling EOL products require the responsible parties to conduct collection, transportation, and recycling operations. Policies that impose physical responsibility can thus be viewed as a form of “command-and-control” regulation.

Regulations that impose physical responsibility are far more restrictive than regulations that impose financial responsibility. The latter require only that producers underwrite these activities, which enables them to decide which (if any) they will conduct themselves and which they will outsource. Assuming producers choose to conduct activities that they can do more costeffectively than the market and outsource the others to the market, regulations that impose financial responsibilities will result in lower costs than those that impose physical responsibilities. 


\section{Collective responsibility and design incentives}

Take-back polices can require manufacturers to be responsible for their own EOL products (“individual responsibility”), or allow or require all producers within an industry to be responsible for all EOL products in their industry (“collective responsibility”). Recalling that a primary rationale for product take-back regulations is to motivate producers to alter their design process to facilitate disposal and recycling (Mayers et al., 2005), some have argued that this incentive is most effective under individual responsibility, whereby producers are responsible for their own EOL products (Castell, Clift, and Francae, 2004; Toffel, 2003). This logic is based on individual responsibility assuring that companies incur the full costs of collecting and recycling their own products, which supports the key objective of take-back policies of having firms internalize the EOL costs of their products, potentially stimulating changes in product design to reduce these costs. On the other hand, individual responsibility (like physical responsibility, discussed above) constrains producers' choices and therefore can lead to higher implementation costs.

During the drafting process of the EU's WEEE Directive, the trade association Orgalime argued against individual responsibility, urging the EU to give producers the choice of developing collective recycling infrastructures, noting that "[i]ndividual responsibility can be achieved within and is compatible with collectively set up and operated take-back, treatment and recycling systems” (Orgalime, 2002). Providing this flexibility enables producers to pursue operational strategies that are most cost effective with respect to their circumstances. Some producers have jointly established consortia called Producer Responsibility Organizations (PROs) to manage product recovery for entire product sectors, the collective nature of which enables economies of scale in recycling operations. Because PROs attempt to minimize their transaction costs, many allocate their overall operating costs to producer-members based simply 
on the number of units processed for each, without regard to differences in the recycling costs or residual value of different brands or models.

This practice of PROs charging a uniform fee regardless of product characteristics undermines the policy objective of sending a clear cost signal to producers meant to motivate investments in design changes that reduce recycling costs or increase the residual value of their EOL products. With uniform PRO fees, reduced recycling costs that derive from investments in product design changes will not accrue exclusively to those that make such investments. Instead, the benefits will be diluted. Any value created, such as faster disassembly or lower hazardous material management costs, would accrue to the PRO, which would then charge lower fees to all producer-members including competitors of the firm(s) that made such investments. Incentives to make such investments will be substantially eroded, perhaps to the point that none will be made. Fishbein addresses this issue with her admonition that PRO fees ought to "be structured to assure that a company benefits from designing products that are less wasteful and/or more recyclable; if not, a major benefit of EPR can be lost” (Fishbein, 2000).

In practice, PROs such as Belgium's Recupel have eschewed model-level or even brandlevel fees, preferring the simpler scheme of assessing a common fee for each product type (e.g., computer monitor, laptop). Similarly, Lindhqvist and Lifset noted a lack of "any real attempts" by PROs at "differentiation of the product fees linked to the real costs of handling the various products” (Lindhqvist and Lifset, 2003). The European Recycling Platform, a pan-European PRO established by major electronics producers, allocates its EOL collection, recycling, and disposal costs to its member producers "based on real collection volumes processed by ERP members in relation to their market share within ERP per product category" (European Recycling Platform, 2008). Mayers notes that the 260 PROs across the European Union that deal 
with EOL batteries, packaging, and WEEE recover costs from producers either through fees based on product categories or by allocating actual costs according to each producer's market share of sales (Mayers, 2007). Thus, at best, fees are allocated by brand according to units sold, rather than by the number of models that are recovered, which would provide more appropriate incentives to invest in the design changes that take-back policies were meant to encourage. Sony and other producers have been calling for PRO fee structures that enable individual companies to benefit from their Design for Environment investments. As a Sony manager commented, "PROs could be managed in such a way that producers are made financially responsible for the takeback costs associated with their own products using take-back and recycling processes that are managed collectively, and without incurring prohibitive costs” (Mayers, 2007).

Imposing a flexible fee system would require PRO recycling operations to track model tallies, which could be costly given the proliferation of product models over the past years, any combination of which might arrive on any given day at a PRO's loading dock. With the development of radio frequency and other technologies, cheaper methods might emerge for more easily identifying models at recycling operations, which could lead to a more precise cost allocation to producers and to a restoration of design incentives.

\section{Advanced disposal fees based on recycling costs}

Even if PROs charged the same fee to all producer-members, policy-makers could create an alternative incentive, by influencing effective product prices, to encourage producers to invest in design changes that reduce EOL product management costs. Specifically, policy makers could impose advanced recycling fees that vary by product model commensurate with the EOL management cost relative to competing products. Models that are cheaper to recycle, because they are easier to disassemble or possess materials more valuable on secondary markets, should be assessed lower fees. This would essentially operate as a sliding tax that rewards or penalizes 
models based on design features that affect their EOL management costs. These fees should reflect estimates of actual recycling costs and be transferred to the appropriate PRO, or directly to the producer if it individually manages its EOL products. Unfortunately, most legislation that imposes advanced recycling fees does so by mandating uniform product fees by product category regardless of brand and model. Under these circumstances, PRO's must initiate product standards for deconstruction and recyclability to close the loop with manufacturers to enable design for the environment. Policies that impose uniform fees should be reviewed in light of the disincentives they can create.

\section{Protecting occupational health and safety}

Dismantling and recycling EOL products creates occupational health and safety risks, especially when the individuals conducting these activities are not protected by enforced regulations. Most of the nearly two million monitors recycled in 1997 were exported for disassembly and processing (Fisher, 2000). A great deal of WEEE recycling takes place in countries such as China, India, Pakistan, and the Philippines that have inexpensive labor and lack rigorously enforced health and safety regulations, which has resulted in very hazardous working conditions (Puckett et al., 2002; Schoenberger, 2002; Silicon Valley Toxics Coalition, Californians Against Waste, and Materials for the Future, 2001). In the United States, prison labor has been used to dismantle WEEE, which also evokes concern because these individuals are exempt from many federal health and safety regulations and inmates who report problems risk retribution (Davis and Smith, 2003). The poor working conditions found in many venues that have recently emerged to dismantle and recycle WEEE have led to calls for governmental and private sector approaches to improve occupational safety and health conditions. 
The most pertinent government policy related to this issue is the Basel Convention on the Control of Transboundary Movements of Hazardous Wastes and Their Disposal (Basel Convention), an international treaty that took effect in 1992. Of the 170 parties to the convention, only Afghanistan, Haiti, and the United States have failed to ratify it (Basel Convention, 2008). By ratifying the convention, potential WEEE exporting nations such as EU member countries and Japan have agreed to ensure that their exporters honor national import bans on hazardous waste and, when shipping to countries that allow such imports, require exporters to obtain written acknowledgement that the importing country will accept each hazardous waste shipment. Parties to the convention, which also include WEEE importers such as China, India, and Pakistan, are required to uphold equivalent terms even when importing from or exporting to countries that have not ratified the convention such as the United States.

The more substantive 1995 Basel Ban Amendment, if and when it takes effect, would prohibit members of the EU and the Organisation for Economic Co-operation and Development (OECD) from exporting hazardous waste for final disposal, recycling, or recovery to less developed countries (LDCs) that are non-OECD member states. Three-fourths of its parties must ratify the amendment for it to take effect, which had not yet occurred by early 2008. Although the ban is not binding on any of its signatories, the majority of OECD countries including all EU member states as well as Norway, Liechtenstein, Monaco, and Iceland have nonetheless unilaterally implemented its restrictions (Puckett et al., 2002).

The United States has ratified neither the Basel Convention nor the Basel Ban. No US law prevents the export of hazardous wastes from the United States to LDCs for disposal, recovery, or recycling. The US Resource Conservation and Recovery Act (RCRA) requires only that exporters of waste to LDCs notify the US Environmental Protection Agency prior to 
disembarking of the waste quantity, destination, and transportation and disposal methods, and obtain written consent from the destination country. At least one environmental pressure group has called for US legislation that imposes export restrictions similar to those adopted by the EU (Electronics Take Back Coalition, 2008).

Because international treaties such as the Basel Convention are difficult to enforce, and the more stringent Basel Ban has yet to take effect, some public interest groups are encouraging companies to enforce the terms of these agreements through their supply chains. For example, the Electronics Take-Back Coalition and the Basel Action Network, two non-governmental organizations, have developed a code of conduct called the "Manufacturer's Commitment to Responsible E-Waste Recycling” that calls on companies to adopt three practices:

- comply with the terms of the Basel Convention and Basel Ban irrespective of whether these agreements are in legal force in any particular country;

- avoid relying on prison labor for any recycling or disassembly of hazardous electronic waste; and

- make "every reasonable effort...to control all hazardous electronic wastes and manage their disposal as hazardous waste and therefore prevent them from entering solid waste landfills or incinerators” (Electronics Take Back Coalition, 2008).

This commitment, which had been signed only by Sony Electronics USA as of January 2008, covers all electronic waste generated by the manufacturer's operations worldwide, whether directly via manufacturing or indirectly via take-back programs, and applies to recycling operations anywhere in the world regardless of the status of international treaties and stringency or enforcement of domestic regulations, even among recycling operations (such as those that use prison labor) that might be exempt from domestic regulations. 


\section{Discussion}

This article has developed a framework for evaluating the extent to which regulations that extend producers' responsibilities to manage their EOL products offer the potential to reduce their environmental impact in an effective and cost-efficient manner, while providing adequate occupational health and safety protection. This evaluation framework can be applied to assess a wide variety of take-back policies that target EOL products such as electronics, batteries, vehicles, and packaging. Data will become increasingly available as time passes, enabling researchers to empirically test the concepts presented in this article based on performance metrics already emerging (Gerrard and Kandlikar, 2007; Mayers et al., 2005).

Extending our framework represents another opportunity for future research. While prior researchers have developed models that illustrate the system-wide costs and environmental impacts associated with various levels of recycling targets (Bloemhof-Ruwaard et al., 1996; Quariguasi Frota Neto et al., 2008), research has just begun to examine the impact of mandatory collection targets (e.g., Walter and Spengler, 2005), which the EU WEEE Directive requires. Stipulating higher collection targets than recycling targets, to the extent that it results in even greater amounts of materials being recovered, can reduce prices and thus lead to greater substitution for virgin materials. If demand for this additional material fails to materialize, however, segregated collection of the additional material could waste transportation and collection resources and might even become a source of pollution. Future research should determine whether and how mandatory collection targets above and beyond recycling targets can elicit environmental benefits, and which products and materials make good candidates for these dual targets. 
More research is needed to identify which EOL products make good targets for take-back policies. Only tentative steps have been taken to address this question. For example, Rose suggests that the decision to remanufacture, disassemble and then recycle, recycle without prior disassembly, or simply dispose of an EOL product is based on product durability, rate of technological obsolescence, product complexity, duration of a design cycle, and reason for redesigns (among other factors) (Rose, 2000). Some have argued that remanufacturing is particularly well suited to EOL products the components of which feature slow technological obsolescence, and when ex ante uncertainty regarding usage intensity results in "overengineering for certain user groups in order to meet the needs of other user groups” (Klausner and Henderickson, 2000). To reduce environmental impact, EPR regulations should target two types of products: (1) those that if diverted from landfills and incinerators would reduce downstream environmental harm; and (2) those that if recovered would provide materials that substitute for more environmentally harmful virgin substances. In practice, determining the appropriate scope of coverage depends on the extent to which scientific evidence determines a product's or material's toxicity, and much of this science is still in its infancy. Indeed, some legislation permits regulators to broaden the scope of EPR regulations to include additional substances as scientific evidence emerges demonstrating toxicity concerns.

Finally, product take-back regulations have evoked concerns about international trade. Although one EU case has addressed the international trade implications of a Danish law that requires all beer and soft drinks to be sold exclusively in returnable containers (Kromarek, 1990; von Moltke, 1993), little research has investigated the implications of take-back regulations on international treaties including whether they violate obligations imposed by the General Agreement on Tariffs and Trade and the World Trade Organization's Agreement on Technical 
Barriers to Trade, as alleged by the American Electronics Association (Scigliano, 1999), and whether such regulations are consistent with the Basel Convention on the Control of Transboundary Movements of Hazardous Wastes and their Disposal, and the pending Basel Ban.

\section{References}

Atlee, J. and Kirchain, R. 2006. Operational sustainability metrics assessing metric effectiveness in the context of electronics-recycling systems. Environmental Science and Technology, 40(14): 4506-4513.

Barba-Gutierrez, Y., Adenso-Diaz, B., and Hopp, M. 2008. An analysis of some environmental consequences of European electrical and electronic waste regulation. Resources, Conservation and Recycling, 52(3): 481-495.

Basel Convention; Basel Convention: Parties to the Basel Convention; www.basel.int/ratif/convention.htm; January 30, 2008.

Bloemhof-Ruwaard, J. B., Van Wassenhove, L. N., Gabel, H. L., and Weaver, P. M. 1996. Environmental Life Cycle Optimization model for the European pulp and paper industry. Omega, an international journal of management science, 24(6): 615-629.

Brinkley, A., Kirby, J. R., Wadehra, I. R., Besnainou, J., Coulon, R., and Goybet, S. 1994. Life Cycle Inventory of PVC: Disposal Options for a PVC Monitor Housing. Research Triangle Park: IBM Corporation.

Bush, G. W. 2007. Strengthening Federal Environmental, Energy, and Transportation Management: Executive Order 13423. In W. House (Ed.).

California Department of Toxic Substance Control. 2001. Emergency Regulations for Cathode Ray Tubes-Findings of Emergency (R-01-06).

Castell, A., Clift, R., and Francae, C. 2004. Extended producer responsibility policy in the European Union: A horse or a camel? Journal of Industrial Ecology, 8(1-2): 4-7.

Crotty, J. 2006. Greening the supply chain? The impact of take-back regulation on the UK automotive sector. Journal of Environmental Policy and Planning, 8(3).

Crotty, J. and Smith, M. 2006. Strategic responses to environmental regulation in the U.K. automotive sector: The European Union End-of-Life Vehicle Directive and the Porter hypothesis. Journal of Industrial Ecology, 10(4): 95-111. 
Davis, S. and Smith, T. 2003. Corporate Strategies for Electronics Recycling: A Tale of Two Systems. San Jose: Silicon Valley Toxics Coalition and the Computer Take Back Campaign.

EIATRACK; Design for Environment in European Union; http://www.eiatrack.org/s/46; February 29, 2008, 2008.

Electronics Take Back Coalition; Electronics Take-Back Campaign. Responsible Recycling.; http://www.computertakeback.com/responsible_recycling/manufacturers_pledge.cfm, January 3, 2008.

Enviros. 2002. Recycled Glass Market Study and Standards Review - 2003 Update. Banbury, United Kingdom: The Waste and Resources Action Programme (WRAP).

EPEAT; Electronic Product Environmental Assessment Tool: The Criteria; http://www.epeat.net/criteria.aspx; January 29, 2008.

European Commission. 2002. Commission Welcomes Agreement on Waste Electrical and Electronic Equipment and the Restriction of Hazardous Substances: European Commission.

European Parliament and European Council. 2003a. Directive 2002/96/EC of the European Parliament and of the Council of 27 January 2003 on waste electrical and electronic equipment (WEEE). Official Journal of the European Union, L 37, 13.2.2003: 24-38.

European Parliament and European Council. 2003b. Directive 2002/95/EC of the European Parliament and of the Council of 27 January 2003 on the restriction of the use of certain hazardous substances in electrical and electronic equipment. Official Journal of the European Union, L 37, 13.2.2003: 19-23.

European Parliament and European Council. 2003c. Directive 2002/96/EC of the European Parliament and of the Council of 27 January 2003 on waste electrical and electronic equipment (WEEE). Official Journal of the European Union, L 37, 13.2.2003: 24-38

European Parliament and European Council. 2005. Directive 2005/32/EC of the European Parliament and of the Council of 6 July 2005 establishing a framework for the setting of ecodesign requirements for energy-using products. Official Journal of the European Union, L 191, 22.7.2005: 29-58.

European Recycling Platform; Press Kit; http://www.erp-recycling.org; January 21, 2008.

Ferrao, P., Nazareth, P., and Amaral, J. 2006. Strategies for meeting EU end-of-life vehicle reuse/recovery targets. Journal of Industrial Ecology, 10(4): 77-93. 
Fishbein, B. K. 2000. Carpet take-back: EPR American style. Environmental Quality Management, 10(1): 25-36.

Fisher, J.; Poison PCs; http://archive.salon.com/tech/feature/2000/09/18/toxic_pc/index.html?source=search\&ai m=/tech/feature; January 21, 2008.

Gerrard, J. and Kandlikar, M. 2007. Is European end-of-life vehicle legislation living up to expectations? Assessing the impact of the ELV Directive on 'green' innovation and vehicle recovery. Journal of Cleaner Production, 15(1): 17-27.

Hanisch, C. 2000. Is extended producer responsibility effective? Environmental Science and Technology, 34(7): 170A-175A.

Hischier, R., Wager, P., and Gauglhofer, J. 2005. Does WEEE recycling make sense from an environmental perspective?: The environmental impacts of the Swiss take-back and recycling systems for waste electrical and electronic equipment (WEEE). Environmental Impact Assessment Review, 25(5): 525-539.

Huisman, J. 2004. QWERTY and Eco-Efficiency Analysis on Cellular Phone Treatment in Sweden. Delft, Netherlands: TU Delft.

Huisman, J., Stevels, A., Marinelli, T., and Magalini, F. 2006. Where did WEEE go Wrong in Europe? Paper presented at the IEEE International Symposium on Electronics and the Environment.

Hunter, D., Salzman, J., and Zaelke, D. 2002. International Environmental Law and Policy. New York, NY: Foundation Press.

Huppes, G. and Ishikawa, M. 2005. Eco-efficiency and Its terminology. Journal of Industrial Ecology, 9(4): 43-46.

Japan's Ministry of Economy Trade and Industry. 2006. Obligation to Provide Information on Chemical Substances Contained in Home Appliances and PCS from July 1, 2006: Japan's Ministry of Economy, Trade and Industry.

Klausner, M. and Henderickson, C. 2000. Reverse-logistics strategy for product take-back. Interfaces, 30: 156-165.

Krikke, H. R., Bloemhof-Ruwaard, J., and Van Wassenhove, L. N. 2003. Concurrent product and closed-loop supply chain design with an application to refrigerators. International Journal of Production Research, 41(16): 3689-3719.

Kromarek, P. 1990. Environmental protection and free movement of goods: The Danish Bottles Case: Commission of the European Communities (supported by United Kingdom) $\mathrm{v}$ Kingdom of Denmark. Journal of Environmental Law, 2: 124-134. 
Lindhqvist, T. and Lifset, R. 2003. Can we take the concept of individual producer responsibility from theory to practice? Journal of Industrial Ecology, 7(2): 3-6.

Mayers, C. K., France, C. M., and Cowell, S. J. 2005. Extended producer responsibility for waste electronics: An example of printer recycling in the United Kingdom. Journal of Industrial Ecology, 9(3): 169-189.

Mayers, C. K. 2007. Strategic, financial, and design implications of extended producer responsibility in Europe: A producer case study. Journal of Industrial Ecology, 11(3): 113-131.

McLaren, J., Wright, L., Parkinson, S., and Jackson, T. 1999. A dynamic life-cycle energy model of mobile phone take-back and recycling. Journal of Industrial Ecology, 3(1): 77-91.

Michelsen, O., Magerholm Fet, A., and Dahlsrud, A. 2007. Eco-efficiency in extended supply chains: a case study of furniture production. Journal of Environmental Management, 79: 290-297.

Musson, S. E., Jang, Y. C., Townsend, T. G., and Chung, I. H. 2000. Characterization of lead leachability from cathode ray tubes using the toxicity characteristic leaching procedure. Environmental Science and Technology, 34(20): 4376-4381.

Ogushu, Y. and Kandlikar, M. 2007. Assessing extending producer responsibility laws in Japan. Environmental Science and Technology, 41(13): 4502-4508.

Orgalime. 2002. Orgalime Guidance on Producer Responsibility in the Proposed WEEE Directive: Notes for the Conciliation Process. Brussels: Orgalime.

Pagell, M., Wu, Z., and Murthy, N. N. 2007. The supply chain implications of recycling. Business Horizons, 50(2): 133-143.

People's Republic of China Ministry of Commerce; Measures for Administration of the Pollution Control of Electronic Information Products; http://english.mofcom.gov.cn/aarticle/policyrelease/domesticpolicy/200605/2006050213 2549.html; 2007, January 21, .

Puckett, J., Byster, L., Westervelt, S., Gutierrez, R., Davis, S., Hussain, A., and Dutta, M. 2002. Exporting Harm: The High Tech Trashing of Asia. Seattle and San Jose: Basel Action Network and Silicon Valley Toxics Coalition.

Quariguasi Frota Neto, J., Bloemhof-Ruwaard, J. M., van Nunen, J. A. E. E., and van Heck, E. 2008. Designing and evaluating sustainable logistics networks. International Journal of Production Economics, 111(2): 195-208. 
Quinell, R. A. 2005. WEEE: No fun for manufacturers. Test \& Measurement World, 25(3): 7172.

Rose, C. M. 2000. Design for the Environment: A Method for Formulating Product End-of-Life Strategies. Unpublished Unpublished PhD Dissertation, Stanford University.

Schoenberger, K. 2002. Where computers go to die: Poor cities in China become dumping

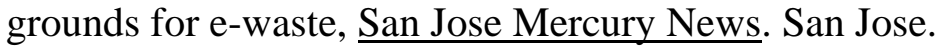

Schoenung, J. M., Ogunseitan, O. A., Saphores, J. D. M., and Shapiro, A. A. 2004. Adopting lead-free electronics: Policy differences and knowledge gaps. Journal of Industrial Ecology, 8(4): 59-85.

Scigliano, E. 1999. Europe may ban today's toxic-laden computers, if the US and WTO don't block it, Seattle Weekly, Vol. November 18. Seattle.

Silicon Valley Toxics Coalition. 1999. Just Say No to e-Waste: Background Document on Hazards and Waste from Computers. San Jose, CA.

Silicon Valley Toxics Coalition, Californians Against Waste, and Materials for the Future. 2001. Poison PCs and Toxic TVs. San Jose: Silicon Valley Toxics Coalition; Californians Against Waste; Materials for the Future.

Toffel, M. W. 2003. The growing strategic importance of end-of-life product management. California Management Review, 45(3): 102.

Toffel, M. W. 2004. Strategic management of product recovery. California Management Review, 46(2): 120.

Toffel, M. W. and Marshall, J. D. 2004. Improving environmental performance assessment: A comparative analysis of weighting methods used to evaluate chemical release inventories. Journal of Industrial Ecology, 8(1-2): 143-172.

Toto, D. 2003. Monitoring the future: CRT glass recyclers speculate on the future of glass-toglass recycling markets - commodity focus - cathode ray tubes. Recycling Today(December).

US Environmental Protection Agency. 1989. Characterization of products containing lead and cadmium in municipal solid waste in the United States, 1970 to 2000. Washington, DC.

US Environmental Protection Agency Office of Solid Waste. 2007. Electronics Waste Management in the United States: Approach 1 (EPA530-R-07-004a). Washington, DC.

von Moltke, K. 1993. Dispute Resolution and Transparency. In G. P. Office (Ed.): 112-135. Washington DC. 
Walter, G. and Spengler, T. 2005. Impact of the WEEE-directive on Reverse Logistics in Germany. International Journal of Physical Distribution and Logistics Management, 35(5): 337-361.

Yang, G. C. C. 1993. Environmental threats for discarded picture tubes and printed circuit boards. Journal of Hazardous Materials, 34: 235-243. 